\title{
Differential Regulation of Superoxide Dismutase Activity in Selected Strawberry Lines Exposed to Mycosphaerella fragariae
}

\author{
Ying Wang ${ }^{1}$, Hana Moidu ${ }^{3}$, Marie Thérèse Charles ${ }^{2}$, Claudine Dubé ${ }^{2} \&$ Shahrokh Khanizadeh $^{3}$ \\ ${ }^{1}$ College of Horticulture, Jilin Agricultural University, Changchun, Jilin Province, P. R. China \\ ${ }^{2}$ Horticulture Research and Development Centre, Agriculture and Agri-Food Canada, 430 Gouin Boulevard, \\ St-Jean-sur-Richelieu, Quebec, Canada \\ ${ }^{3}$ Eastern Cereals and Oilseed Research Centre, Agriculture and Agri-Food Canada, K.W. Neatby Building, \\ Ottawa, Ontario, Canada \\ Correspondence: Shahrokh Khanizadeh, Plant Breeding, Physiology and Statistics, Eastern Cereals and Oilseed \\ Research Centre, Agriculture and Agri-Food Canada, K.W. Neatby Building, Ottawa, Ontario, Canada. Tel: \\ 1-613-759-6563. E-mail: shahrokh.khanizadeh@agr.gc.ca, http://khanizadeh.info
}

Received: December 16, 2013 Accepted: March 13, 2015 Online Published: March 31, 2015

doi:10.5539/jps.v4n2p30

URL: http://dx.doi.org/10.5539/jps.v4n2p30

\begin{abstract}
The effect of leaf infection by the fungus Mycosphaerella fragariae, on total superoxide dismutase activity and induction of SOD isozymes was studied under controlled conditions using four selected strawberry cultivars: Kent (HS, highly susceptible), Joliette (HR, highly resistant) and two advanced strawberry lines, SJ8976-1 and APF029-4 (MR, moderately resistant). Observations were made of conidia morphology of M. fragariae grown in strawberry leaf agar (SLA) at different stages of conidia development and of infective symptoms of the leaves after inoculation. Inoculation of strawberry leaves with $M$. fragariae increased protein content and SOD activities in all four cultivars. In all cases, total SOD increased 1 day (d) after inoculation, reaching a peak $2 \mathrm{~d}$ after inoculation, and slowly declining thereafter. Total SOD activity in Joliette, SJ8976-1 and APF029-4 two days after inoculation was 4376, 4433 and $4283 \mathrm{U} \mathrm{g}^{-1} \mathrm{FW}$, respectively, and significantly was lower for Kent (3656 $\left.\mathrm{U} \mathrm{g}^{-1} \mathrm{FW}\right)$. From the electrophoresis profile of the strawberry cultivars, 2 newly synthesized isozymes were found in infected Joliette and SJ8976-1, $\left(\mathrm{R}_{\mathrm{f}}=0.31\right.$ and 0.34$)$, which are believed to be associated with leaf spot resistance.
\end{abstract}

Keywords: superoxide dismutase, SOD, Kent, Joliette, M. fragariae, synthesized isozymes, leaf spot

\section{Introduction}

During normal cellular activities in plants, various processes, including enzymatic reactions, electron transportation and self-oxidation of small molecules inside the cells, produce reactive oxygen species (ROS), such as singlet oxygen $\left({ }^{1} \mathrm{O}_{2}\right)$, hydrogen peroxide $\left(\mathrm{H}_{2} \mathrm{O}_{2}\right)$, superoxide $\left(\mathrm{O}_{2}^{-}\right)$and hydroxyl radicals $\left(\mathrm{OH}^{*}\right)$ (Hernández et al., 1995; Foyer \& Noctor, 2000; Anderson, 2002). Plant cells can produce ROS when exposed to an unhealthy environment, such as air or metal pollution, UV or water stress, extreme low or high temperatures, pathogen invasion, or herbicide action. In general, ROS are produced in both stressed and non-stressed cells, with the primary sites being the cytosol, chloroplasts, mitochondria, and/or the apoplastic space (Mittler, 2002). There are several mechanisms plants employ to protect them from the toxicity of ROS. Environmental stresses enhance ROS production, resulting in an imbalance between oxidative stress and the detoxification defense systems (Smirnoff, 1998; Kuźniak \& Sklodowska, 2004). To limit the damage initiated by ROS, plants have developed a complex and perfect antioxidant system, which includes a number of enzymatic and non-enzymatic ROS detoxifying agents that are distributed in most cellular compartments and have been well characterized (Bowler et al., 1992; Casano et al., 1994). Superoxide dismutases (SOD, EC 1.15.1.1) are the first scavengers of ROS in enzymatic systems and are crucial in defending cells against the associated effects. SODs are metal chelated enzymes that are present in virtually all organisms, including animals, plants, and microorganisms, except for strict anaerobes, and in subcellular compartments where oxidative stress is likely to arise. These enzymes catalyze the dismutation of superoxide to $\mathrm{H}_{2} \mathrm{O}_{2}$ and $\mathrm{O}_{2}$ (McCord \& Fridovich, 1969); this reaction occurs at a 10 000-fold faster rate than spontaneous dismutation (Bowler et al., 1992). Subsequently, $\mathrm{H}_{2} \mathrm{O}_{2}$ is catalyzed into $\mathrm{H}_{2} \mathrm{O}$ and $\mathrm{O}_{2}$ by catalase (CAT) and various kinds of peroxidase (POD), such as PAX and the 
ascorbate-glutathione cycle.

Leaf spot, caused by Mycosphaerella fragariae, is a common foliar disease of strawberry in North America (Dale \& Fulton, 1957; Fall, 1951; Fulton, 1958; Plakidas, 1965). In earlier years it was considered the most devastating strawberry disease due to its detrimental economic impact. With increased emphasis on the development and use of resistant cultivars, leaf spot, although still an important foliar disease, is now of less concern (Maas, 1984). Strawberry cultivars differ in their sensitivity to leaf spot; host and environmental conditions during infection are factors that affect the lesions produced by M. fragariae (Delhomez et al., 1995; Carisse et al., 2000). Joliette is HR (highly resistant) and Kent HS (highly susceptible) (Delhomez et al., 1995; Khanizadeh et al., 1996). Based on examination and observations of infected leaves in a production context, the two selected strawberry lines, SJ8976-1 and APF029-4, are considered to be MR (moderately resistant).

The objective of this y research was to analyze the activity of SOD during infection of the four strawberry cultivars by leaf spot disease.

\section{Materials and Method}

\subsection{Plant Material and Inoculation}

Forty plants of four strawberry cultivars (Fragaria $\times$ ananassa Duchesne)-Kent (HS), Joliette (HR) and two selected lines, SJ8976-1 and APF029-4 (MR) - were propagated by stolons into 160 pots containing sand, peat moss, and mineral soil in a ratio of $1: 1: 1$ by volume. Plantlets were grown in a greenhouse for 2 months at $25^{\circ} \mathrm{C}$ with a 16-h photoperiod, until inoculation.

The method used to produce M. fragariae (Tul.) Lindau (Ramularia tulasnei Sacc.) inoculum was formerly described by Delhomez et al. (1995). Stock cultures were temporarily maintained on potato agar slants at $3{ }^{\circ} \mathrm{C}$. Because pathogenicity may decline during storage, strawberry leaves from Kent were inoculated with the pathogen, and the fungus was re-isolated using a method described by Carisse and Kushalappa (1989), before production of the inoculum. The fungus was then transferred to strawberry leaf agar (SLA) and incubated at room temperature $\left(20\right.$ to $\left.25^{\circ} \mathrm{C}\right)$ for 2 weeks. Spores were produced by inoculating the mycelial suspension onto SLA plates $\left(2 \mathrm{~mL} /\right.$ plate), and the spore production plates were incubated at room temperature $\left(20\right.$ to $\left.25^{\circ} \mathrm{C}\right)$ for 1 week. On the day of plant inoculation, a conidial suspension was prepared from the cultures by pouring a solution containing $10 \mathrm{~mL}$ of sterile distilled water and $0.01 \%$ Tween 80 into each plate. Observations of spore morphology were made using an Infinity 2 digital camera mounted on a Leica DM LB microscope. The final spore suspension was adjusted to $1.14 \times 10^{5}$ spores $/ \mathrm{mL}$ using a hemocytometer.

Twenty plants of each cultivar were inoculated by spraying the spore suspension onto both faces of their leaves. The plants were then transferred to a growth chamber and maintained at $25^{\circ} \mathrm{C}$ with a 16 -h photoperiod and high humidity (about 100\%). Another twenty non-inoculated plants, were held in an independent growth chamber under identical conditions and served as controls. After $48 \mathrm{~h}$, the humidity was reduced to $85 \%$ in both chambers until the end of the study.

\subsection{Enzyme Extraction}

Triplicate samples of fully expanded young leaves from the inoculated and control plants were collected 1, 2, 3 , 4,10 , and $20 \mathrm{~d}$ after inoculation. The samples were immediately frozen in liquid nitrogen and stored at $-80{ }^{\circ} \mathrm{C}$ until utilization. All methods of enzyme extraction were performed at $0-4{ }^{\circ} \mathrm{C}$. For total protein extracts, frozen leaves $(0.5 \mathrm{~g})$ were homogenized with a mortar and pestle in $3 \mathrm{~mL}$ of ice-cold $0.05 \mathrm{M}$ sodium phosphate buffer (pH 7.8) containing $1 \mathrm{mM}$ EDTA-Na $2,0.1 \%$ ASA (w/v), $15 \%$ glycerol (v/v), $5 \%$ PVP, $0.1 \%$ Triton X-100, 0.01 $\mathrm{mM}$ phenylmethanesulphonyl fluoride and $0.05 \% \beta$-mercaptoethanol $(\mathrm{v} / \mathrm{v})$. The homogenate was centrifuged at $12000 \mathrm{~g}$ for $20 \mathrm{~min}$ and the supernatant was used for the SOD assay and electrophoresis.

\subsection{SOD Activity}

An adapted version of the method introduced by Beauchamp and Fridovich (1971), which is based on the photo-reduction of nitroblue tetrazolium (NBT), was used to obtain the total SOD activity in the extracts. The reaction mixture consisted of $3 \mathrm{~mL}$ of $0.05 \mathrm{M}$ sodium phosphate buffer ( $\mathrm{pH} 7.8$ ) containing $13 \mathrm{mM}$ methionine, $75 \mu \mathrm{M}$ NBT, $0.01 \mathrm{mM}$ EDTA-Na, $0.002 \mathrm{mM}$ riboflavin, and $0.1 \mathrm{~mL}$ of $25 \%, 50 \%, 75 \%$ and $100 \%$ concentrations of sample. Lastly, Riboflavin was added as a source of superoxide. Cuvettes containing the reaction mixtures were illuminated by two $15-\mathrm{W}$ fluorescent lamps until mixtures without SOD achieved a moderated blue color. The absorbance of the reaction mixtures was measured at $560 \mathrm{~nm}$ using a spectrophotometer (DU 640, Beckman). The non-irradiated reaction mixtures served as controls and were deducted from the $\mathrm{A}_{560}$ of the samples. The volume of the extracts corresponding to $50 \%$ inhibition of the reaction was considered to be one enzyme unit. Total SOD activity was expressed in units per gram fresh weight 
( $\mathrm{U} \mathrm{g}^{-1} \mathrm{FW}$ ), and specific SOD activity in $\mathrm{U} \mathrm{mg}^{-1}$ protein. Total protein content (TPC) of the extracts was quantified by Bradford's method (Bradford, 1976) using BSA as a standard.

\subsection{Native Polyacrylamide Gel Electrophoresis and SOD Visualization}

Thirty $\mu \mathrm{g}$ of concentrated proteins were loaded onto polyacrylamide slab gels $(18 \times 14 \times 0.15 \mathrm{~cm})$ prepared according to Davis (1964), with slight modifications. The concentrations of the stacking and resolving gels were $4 \%$ and $10-12 \%$, respectively. Riboflavin was used for photopolymerization of the gel in place of ammonium persulfate. Electrophoresis was performed at $15-20 \mathrm{~mA}$ for 10 to $12 \mathrm{~h}$, until the bromophenol blue dye marker migrated to the bottom of the gel. The gel was stained by the riboflavin/NBT method (Beauchamp and Fridovich, 1971). For the comparison of different isozymes, the relative distance $\left(R_{\mathrm{f}}\right.$ value $)$ of the bands was determined as described by Manganaris and Alston (1992), from the origin of each band $\left(\mathrm{R}_{\mathrm{f}}=0\right)$ and from the migration distance of the dye marker $\left(\mathrm{R}_{\mathrm{f}}=1\right)$.

\subsection{Statistical Analysis}

Data were analyzed using the ANOVA and GLM procedures of SAS (1989), and the means were separated using the least significant difference (LSD) test at the 0.05 level.

\section{Results}

\subsection{Conidia Observation and Symptoms of Infected Strawberry Leaves}

M. fragariae conidia are elliptical to cylindrical, hyaline, and 0-4 septate. They measure $20-40 \times 3-5 \mu \mathrm{m}$ and are often formed in short chains (Figure 1). Conidiophores are short, hyaline, unbranched, and frequently curved or bent; they have prominent conidial scars, as described by Maas (1984).

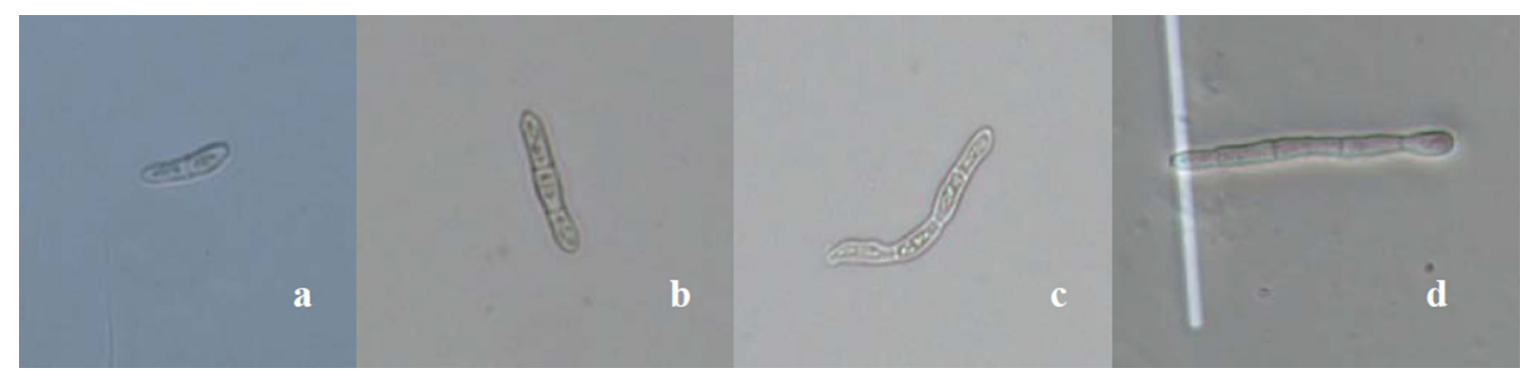

Figure 1. Conidia of M. fragariae (250×). a, b, c, and d are 1, 2, 3, and 4 septate conidia, respectively

Symptoms of leaf spot first appear as circular, deep purple spots on the upper leaf surface. These spots enlarge and the centers turn brown to grayish and then white on older leaves. A definite reddish purple to rusty brown border surrounds the spots. Colonization of strawberry leaf tissues by M. fragariae $30 \mathrm{~d}$ after inoculation caused macroscopic red spots of varying severity depending on the cultivar (Figure 2). From Figure 2, we can see clearly that susceptibility to leaf spot varies by the cultivar. 


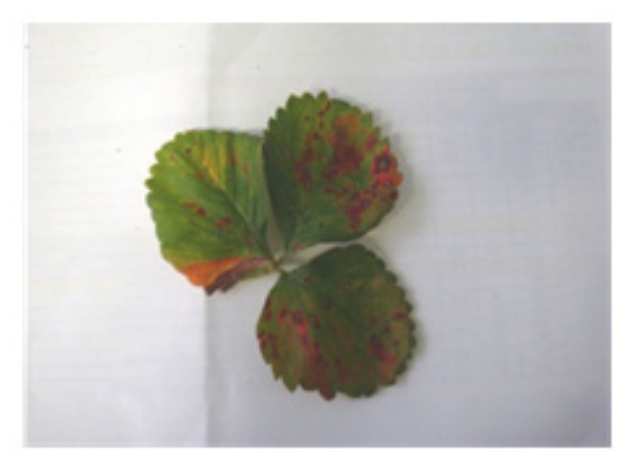

Kent

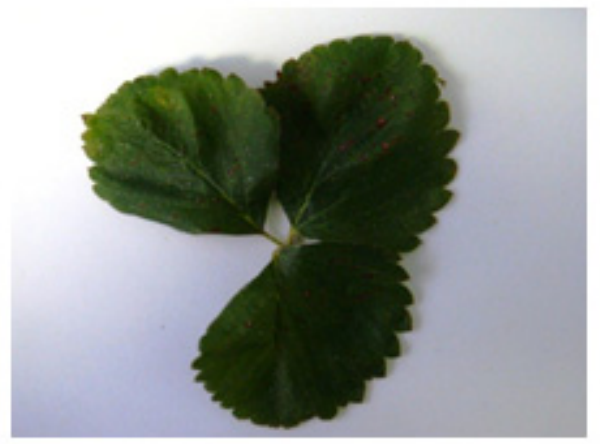

SJ8976-1

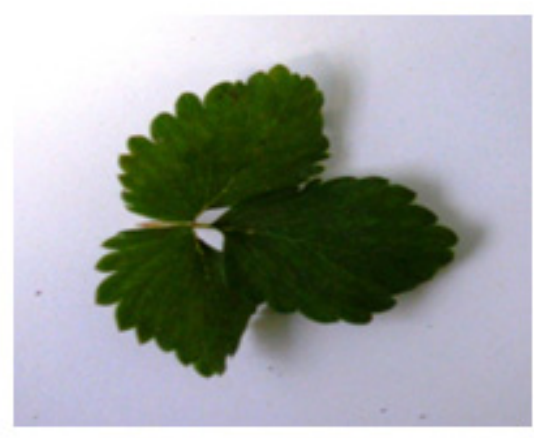

Joliette

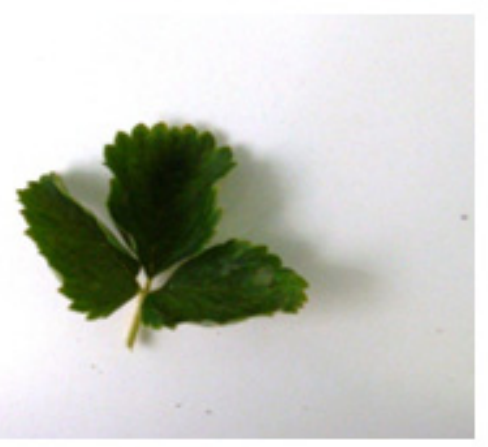

APF029-4

Figure 2. Leaf spot lesions caused by M. fragariae on Kent (HS), Joliette (HR) and SJ8976-1 and APF029-4 (MR) 1 month after inoculation

\subsection{Analysis of SOD Activity}

TPC and total and specific SOD activities for Kent, Joliette, SJ8976-1, and APF029 up to $20 \mathrm{~d}$ after inoculation with M. fragariae, are presented in Table 1. 
Table 1. TPC and total and specific SOD activities of the four strawberry cultivars inoculated by M. fragariae

\begin{tabular}{|c|c|c|c|c|}
\hline Cultivar & $\begin{array}{l}\text { Day after } \\
\text { inoculation }\end{array}$ & $\begin{array}{l}\text { Total protein content } \\
\text { (mg g-1 FW) }\end{array}$ & $\begin{array}{l}\text { Total SOD activity } \\
\text { (U g-1 FW) }\end{array}$ & $\begin{array}{l}\text { Specific SOD activity } \\
\text { (U mg-1 protein) }\end{array}$ \\
\hline \multirow[t]{7}{*}{ Kent } & 0 & $5.50 \mathrm{~b}$ & $2245 b$ & $408 \mathrm{~d}$ \\
\hline & 1 & $5.79 \mathrm{~b}$ & $2540 \mathrm{~b}$ & $438 \mathrm{~cd}$ \\
\hline & 2 & $7.22 \mathrm{a}$ & $3656 a$ & $506 \mathrm{~cd}$ \\
\hline & 3 & $7.07 \mathrm{a}$ & $3420 a$ & $483 \mathrm{~cd}$ \\
\hline & 4 & $5.00 \mathrm{c}$ & $2561 b$ & $513 c$ \\
\hline & 10 & $3.58 \mathrm{~d}$ & $2273 b$ & $637 \mathrm{~b}$ \\
\hline & 20 & $3.05 \mathrm{e}$ & $2310 b$ & $757 a$ \\
\hline $\operatorname{LSD}_{0.05}$ & - & 0.39 & 346.38 & 60.23 \\
\hline${ }^{\mathrm{a}} \mathrm{OC}$ & - & $2.54 \mathrm{~ns}$ & $19.72^{* *}$ & $47.76^{* * *}$ \\
\hline${ }^{\mathrm{b}} \mathrm{OPC}$ & - & $\mathrm{L}^{* * *}$ & $\mathrm{~ns}$ & $\mathrm{~L}^{* * *}$ \\
\hline \multirow[t]{7}{*}{ Joliette } & 0 & $5.09 b c$ & $2197 d$ & $432 d$ \\
\hline & 1 & $5.34 \mathrm{~b}$ & $3729 b$ & $699 \mathrm{~b}$ \\
\hline & 2 & $5.86 \mathrm{a}$ & $4376 a$ & $746 \mathrm{ab}$ \\
\hline & 3 & $5.39 \mathrm{~b}$ & $3624 b$ & $673 b c$ \\
\hline & 4 & $5.21 b c$ & $3137 \mathrm{c}$ & $602 c$ \\
\hline & 10 & $4.96 c$ & $2961 \mathrm{c}$ & $596 \mathrm{c}$ \\
\hline & 20 & $3.01 \mathrm{~d}$ & $2397 d$ & $798 \mathrm{a}$ \\
\hline $\operatorname{LSD}_{0.05}$ & - & 0.38 & 319.63 & 58.37 \\
\hline${ }^{\mathrm{a}} \mathrm{OC}$ & - & $0.83 \mathrm{~ns}$ & $106.36^{* * *}$ & $149.44^{* * *}$ \\
\hline${ }^{\mathrm{b}} \mathrm{OPC}$ & - & $\mathrm{L}^{* * *}$ & $\mathrm{~L}^{*}$ & $\mathrm{~L}^{*}$ \\
\hline \multirow[t]{7}{*}{ SJ8976-1 } & 0 & $5.40 \mathrm{~d}$ & $2274 \mathrm{e}$ & $422 \mathrm{e}$ \\
\hline & 1 & $5.90 \mathrm{c}$ & $3689 \mathrm{c}$ & $625 \mathrm{c}$ \\
\hline & 2 & $7.11 \mathrm{a}$ & $4433 a$ & $623 c$ \\
\hline & 3 & $6.92 \mathrm{ab}$ & $4208 b$ & $609 \mathrm{c}$ \\
\hline & 4 & $6.52 \mathrm{~b}$ & $3535 c$ & $543 d$ \\
\hline & 10 & $4.61 \mathrm{e}$ & $3048 d$ & $663 b$ \\
\hline & 20 & $3.07 \mathrm{f}$ & $3188 d$ & $1038 \mathrm{a}$ \\
\hline $\operatorname{LSD}_{0.05}$ & - & 0.41 & 200.61 & 21.77 \\
\hline${ }^{\mathrm{a}} \mathrm{OC}$ & - & $4.00 \mathrm{~ns}$ & $389.60^{* * *}$ & $1140.85^{* * *}$ \\
\hline${ }^{\mathrm{b}} \mathrm{OPC}$ & - & $\mathrm{L}^{* * *}$ & $\mathrm{~ns}$ & $\mathrm{~L}^{* * *}$ \\
\hline \multirow[t]{7}{*}{ APF029-4 } & 0 & $4.88 \mathrm{~d}$ & $2808 d$ & $577 \mathrm{~cd}$ \\
\hline & 1 & $5.91 \mathrm{c}$ & $3661 b c$ & $619 \mathrm{c}$ \\
\hline & 2 & $7.22 \mathrm{a}$ & $4283 a$ & $593 \mathrm{~cd}$ \\
\hline & 3 & $7.16 \mathrm{ab}$ & $3940 \mathrm{~b}$ & $550 \mathrm{de}$ \\
\hline & 4 & $6.51 b c$ & $3366 c$ & $516 \mathrm{e}$ \\
\hline & 10 & $4.20 \mathrm{e}$ & $2884 d$ & $687 \mathrm{~b}$ \\
\hline & 20 & $3.29 \mathrm{f}$ & $2958 d$ & $901 \mathrm{a}$ \\
\hline $\operatorname{LSD}_{0.05}$ & - & 0.46 & 301.9 & 48.26 \\
\hline a $\mathrm{OC}$ & - & $26.65^{* *}$ & $43.09^{* * *}$ & $15.25^{*}$ \\
\hline${ }^{\mathrm{b}} \mathrm{OPC}$ & - & $\mathrm{L}^{* *}$ & $\mathrm{~L}^{*}$ & $\mathrm{~L}^{* * *}$ \\
\hline
\end{tabular}

Triplicate samples of fully expanded young leaves from both control and inoculated plants were collected at 1,2, $3,4,10$, and $20 \mathrm{~d}$ after inoculation. Each value represents the mean of three independent plants. $\mathrm{LSD}_{0.05}$ : Least 
Significant Different at 0.05 level. $*=(\mathrm{P}<0.05), * *=(\mathrm{P}<0.01), * * *=(\mathrm{P}<0.001)$, ns $=$ non-significant $(\mathrm{P}>0.05)$. ${ }^{\mathrm{a} O C}$ : Orthogonal Contrast day 0 vs all days; ${ }^{\mathrm{b}} \mathrm{OPC}$ : Orthogonal polynomial contrast; $\mathrm{L}=$ liner, ns=not significant.

Kent: total SOD activity increased after inoculation, reached a peak after $2 \mathrm{~d}\left(3656 \mathrm{U} \mathrm{g}^{-1} \mathrm{FW}\right)$, and declined slowly thereafter. The orthogonal contrast (OC) value was $19.72^{* *}$, which indicates that, after inoculation, total SOD activity was significantly higher than in the control $\left(2245 \mathrm{U} \mathrm{g}^{-1} \mathrm{FW}\right)$, although there were no significant linear effects. TPC reached its highest peak after $2 \mathrm{~d}\left(7.22 \mathrm{mg} \mathrm{g}^{-1} \mathrm{FW}\right)$, showing an increase of $112 \%$ relative to the control $\left(5.50 \mathrm{mg} \mathrm{g}^{-1} \mathrm{FW}\right)$. Although there was no significant difference between the control and all other days for TPC, inoculation showed a significant linear effect. Specific SOD activity (enzyme concentration based on total protein, $\mathrm{U} \mathrm{mg}^{-1}$ protein) showed a significant linear effect.

Joliette: total SOD activity increased after inoculation, reached its highest level after $2 \mathrm{~d}\left(4376 \mathrm{U} \mathrm{g}^{-1} \mathrm{FW}\right)$ and slowly declined thereafter. Inoculation had a significant linear effect on total SOD activity, which was very pronounced in the control vs. all other days $\left(\mathrm{OC}=106.36^{* * *}\right)$. As with Kent, the highest TPC value was recorded after $2 \mathrm{~d}\left(5.86 \mathrm{mg} \mathrm{g}^{-1} \mathrm{FW}\right)$. Although there was no significant difference between the control and all other days for TPC, inoculation showed significant linear effects. Specific SOD activity showed a significant positive linear effect.

SJ8976-1: as in the case of Kent and Joliette, total SOD activity increased after inoculation, reached its highest level after $2 \mathrm{~d}\left(4433 \mathrm{U} \mathrm{g}^{-1} \mathrm{FW}\right)$ and slowly declined thereafter. Total SOD activity was significantly higher than for the control (2274 $\left.\mathrm{U} \mathrm{g}^{-1} \mathrm{FW}\right)$; however, no significant linear effect was found after inoculation by $M$. fragariae. The TPC value was recorded after $2 \mathrm{~d}\left(7.11 \mathrm{mg} \mathrm{g}^{-1} \mathrm{FW}\right)$, showing an increase of $133 \%$ relative to the control value $\left(5.40 \mathrm{mg} \mathrm{g}^{-1} \mathrm{FW}\right)$. There was no significant difference between the control and all other days for TPC; however, inoculation showed significant linear effects. Specific SOD activity showed significant positive linear effects after inoculation.

APF029-4: as in the case of the other three cultivars, total SOD activity increased after inoculation, reaching its highest level after $2 \mathrm{~d}\left(4283 \mathrm{U} \mathrm{g}^{-1} \mathrm{FW}\right)$, then slowly declined thereafter. Inoculation had a significant linear effect on total SOD activity; the effect was very pronounced for the control compared with all other days $(\mathrm{OC}=$ $\left.43.09^{* * *}\right)$. The variation in TPC was similar to that for total and specific SOD activities, with inoculation showing a significant linear effect.

For Kent, Joliette, SJ8976-1 and APF029-4, the lowest level of TPC was recorded after 20 d: 3.05, 3.01, 3.07 and $3.29 \mathrm{mg} \mathrm{g}^{-1} \mathrm{FW}$, respectively.

Figure 3 illustrates the variation of total SOD activity in the four cultivars on different days after inoculation with $M$. fragariae. Total SOD activity was significantly higher in APF029-4 than in the other three cultivars on the control day, but increased in all four cultivars after inoculation. There was no significant difference between Joliette, SJ8976-1 and APF029-4, with all three cultivars showing significantly higher effects than Kent 1, 2, 4 and $10 \mathrm{~d}$ after inoculation. Total SOD activity was significantly higher in SJ8976-1 and APF029-4 than in Kent and Joliette $20 \mathrm{~d}$ after inoculation. 


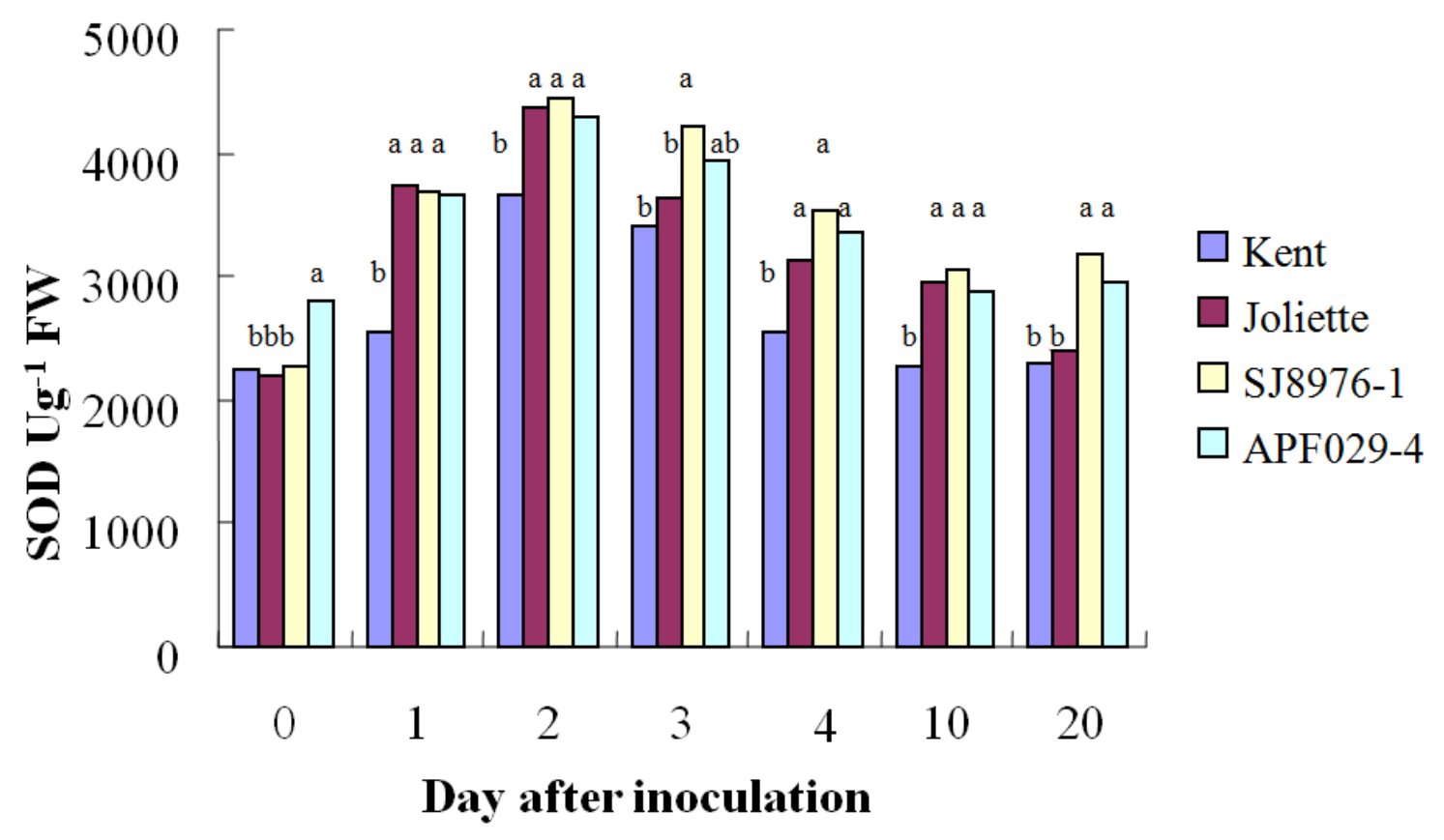

Figure 3. The effect of $M$. fragariae infection on total SOD activity in the four strawberry cultivars $20 \mathrm{~d}$ after inoculation. Triplicate samples of fully expanded young leaves from both control $(0 \mathrm{~d})$ and inoculated plants were collected at 1, 2, 3, 4, 10, and $20 \mathrm{~d}$ after inoculation. Each bar is the average of three independent plants.

Bar with different letter whithin the same cultivars are significantly different $(P \leq 0.05)$

\subsection{Native PAGE}

Native polyacrylamide gel electrophoresis (PAGE) was performed on the samples several times, giving similar results. For this reason, the data from only two experiments are discussed. The isozyme pattern of SOD changed between the four cultivars in response to inoculation with $M$. fragariae (Figure 4 and Figure 5).

Initially, a total of $14,13,13$ and 15 SOD isozymes were detected in the control plants of Kent, Joliette, SJ8976-1 and APF029-4, respectively. After inoculation, Kent and APF029-1 showed no difference; however, the number of SOD isozymes in Joliette and SJ8976-1 increased to 15 with the identification of two newly synthesized SOD isozymes (i.e., $\mathrm{R}_{\mathrm{f}}=0.31$ and 0.34 ) without reduction of bands. It is considered that the two synthesized SOD isozymes are associated with leaf spot resistance.

In the present study, inoculation also affected the intensity of the isozymes bands, which became more intense and thicker in the 4 inoculated strawberry cultivars as compared to the controls. 

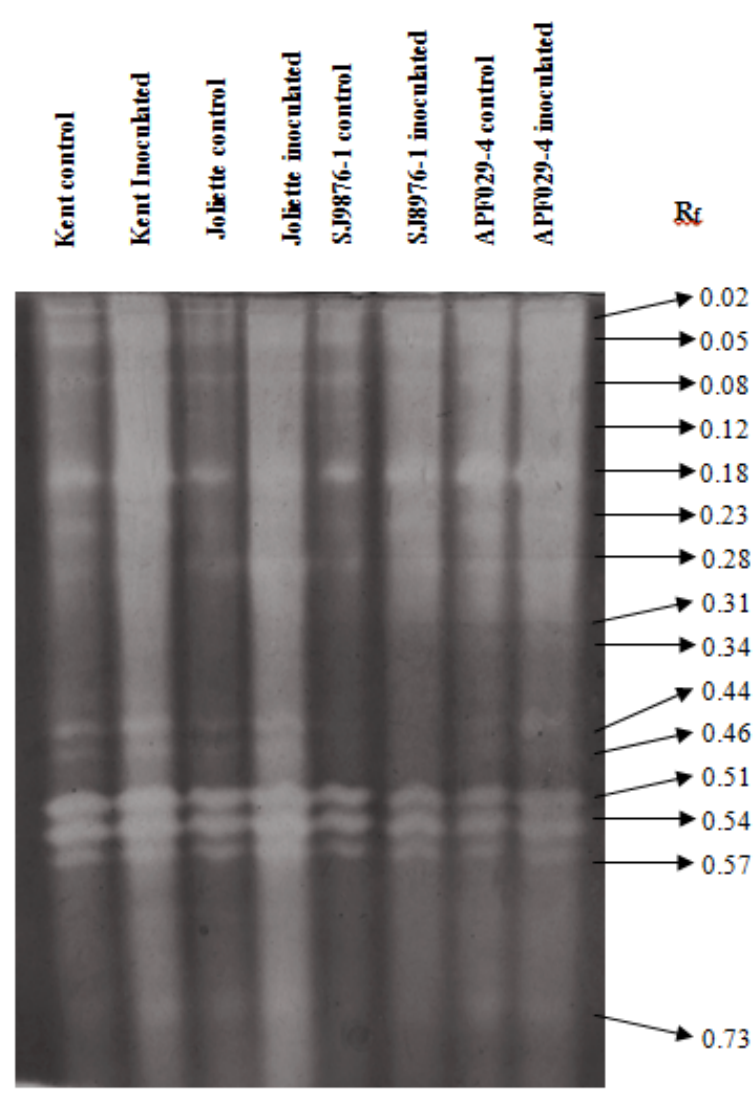

\begin{tabular}{lllllllll}
\hline \multirow{2}{*}{$R_{f}$} & Kent & & \multicolumn{2}{l}{ Joliette } & & \multicolumn{2}{l}{ SJ8976-1 } & \multicolumn{3}{l}{ APF029-4 } \\
\cline { 2 - 9 } & Control & Inoculated & Control & Inoculated & Control & Inoculated & Control & Inoculated \\
\hline 0.02 & 1 & 1 & 1 & 1 & 1 & 1 & 1 & 1 \\
0.05 & 1 & 1 & 1 & 1 & 1 & 1 & 1 & 1 \\
0.08 & 1 & 1 & 1 & 1 & 1 & 1 & 1 & 1 \\
0.12 & 1 & 1 & 1 & 1 & 1 & 1 & 1 & 1 \\
0.18 & 1 & 1 & 1 & 1 & 1 & 1 & 1 & 1 \\
0.23 & 1 & 1 & 1 & 1 & 1 & 1 & 1 & 1 \\
0.28 & 1 & 1 & 1 & 1 & 1 & 1 & 1 & 1 \\
0.31 & 0 & 0 & 0 & 1 & 0 & 1 & 1 & 1 \\
0.34 & 1 & 1 & 0 & 1 & 0 & 1 & 1 & 1 \\
0.44 & 1 & 1 & 1 & 1 & 1 & 1 & 1 & 1 \\
0.46 & 1 & 1 & 1 & 1 & 1 & 1 & 1 & 1 \\
0.51 & 1 & 1 & 1 & 1 & 1 & 1 & 1 & 1 \\
0.54 & 1 & 1 & 1 & 1 & 1 & 1 & 1 & 1 \\
0.57 & 1 & 1 & 1 & 1 & 1 & 1 & 1 & 1 \\
0.73 & 1 & 1 & 1 & 1 & 1 & 1 & 1 & 1 \\
\hline
\end{tabular}

Figure 4. Isozyme pattern of SOD activity of four strawberry cultivars at $0 \mathrm{~d}$ and $2 \mathrm{~d}$ after inoculation with M. fragariae. Arrows correspond to $\mathrm{SOD}$ bands along with $\mathrm{R}_{\mathrm{f}}$ value in table

$\mathrm{R}_{\mathrm{f}}$ : $=$ Relative distance of the band as described in the Materials and Methods section ( 0 and 1 indicate the presence and absence of SOD bands, respectively). 


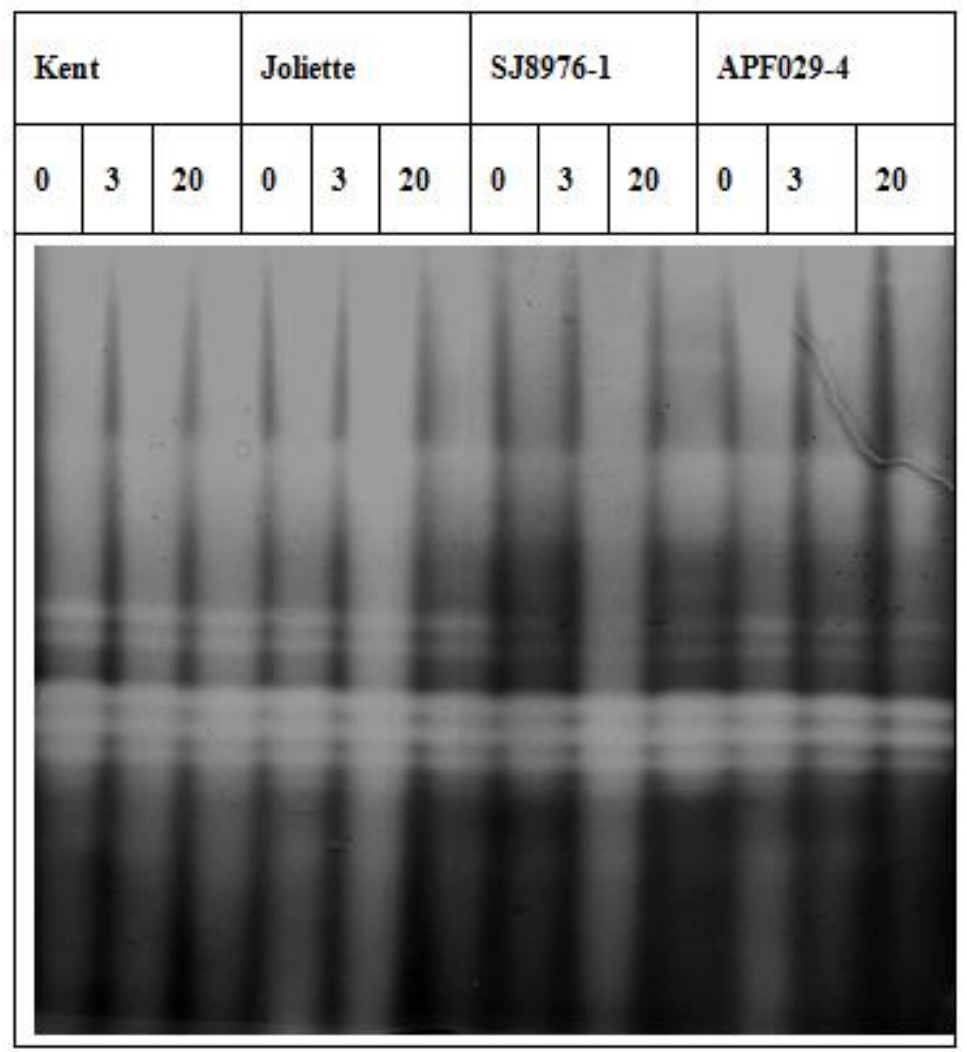

Figure 5. Isozyme pattern of SOD in the four strawberry cultivars at $0 \mathrm{~d}$ and 3 and $20 \mathrm{~d}$ after inoculation with M. fragariae (Kent 0, 3, $20 \mathrm{~d}$; Joliette 0, 3, $20 \mathrm{~d}$; SJ8976-1 0, 3, $20 \mathrm{~d}$ and APF029-4 0, 3, $20 \mathrm{~d}$ from left to right, respectively)

\section{Discussion}

Environmental stresses lead to increased ROS production in plant cells, which can damage proteins, membrane lipids, DNA and other cellular components. Tolerance to various environmental stresses, such as pathogen attack in plants (Reuveni et al., 1992; Miyazawa et al., 1998; Ros Barceló et al., 2003; Kuźniak \& Sklodowska, 2004; Moghaddam et al., 2006)., has been known to be associated with both antioxidant concentrations in plants as well as the activity of ROS scavenging enzymes (Chaitanya et al., 2002).

SOD enzymes protect against ROS and play a key role in the biology of cells and tissues. These enzymes have therefore become a focus of research in the fields of botany, biochemistry and biology as well as in medical, food, animal and veterinary sciences. SOD activity has been reported to increase under stress conditions such as high irradiance, low temperature, air pollutants, etc. (Tsang et al., 1991; Scandalios, 1993). Changes in SOD activity are used as an indicator of changes in superoxide production, since the level of SOD production depends on superoxide production (Wang et al., 2004).

Various environmental stresses can induce SOD gene expression. Total SOD activity has been found to increase in maize, wheat, tobacco and other plants following exposure to herbicides, illumination, heat shock, mechanical damage and ethylene (Perl-Treves \& Galun, 1991; Matters \& Scandalios, 1986; Tsang et al., 1991; Wu et al., 1999). Kuźniak and Sklodowska (2004) reported that infection of tomato leaves with the necrotrophic fungus Botrytis cinerea resulted in substantial changes in enzymatic and non-enzymatic components of the ascorbate-glutathione cycle as well as in changes in SOD, glutathione peroxidase (GSH-Px), glutathione transferase (GST), and L-galactono- $\gamma$-lactone dehydrogenase (GLDH) activities. Total SOD activity began to increase $1 \mathrm{~d}$ after inoculation and remained, on average, $66 \%$ higher in the mitochondria of the control plants (Kuźniak \& Sklodowska, 2004). In the present study, we used extracts of non-infected leaves as controls and leaves infected with $M$. fragariae to study SOD activity in response to $M$. fragariae infection. The level of concentration in inoculated strawberry cultivars may be indirect evidence because of the enhancement of superoxide radical production in the plants. In the present study, a significant increase in SOD activity was observed in both resistant and susceptible strawberry plants $2 \mathrm{~d}$ after inoculation, which is similar to what was 
found in the study by Ehsani-Moghaddam et al. in 2006. Joliette, SJ8976-1 and APF029-4 showed significantly higher levels of total SOD activity $2 \mathrm{~d}$ after infection compared to Kent, indicating that these three cultivars have a higher tolerance to the oxidative stress induced by the pathogen.

Changes in SOD activities were examined in leaves of bean (Phaseolus vulgaris L. cv. Tendergreen) undergoing compatible and incompatible interactions to race 6 and race 3 strains, respectively, of the halo-blight bacterium Pseudomonas syringae pv. phaseolicola. Resistance of cv. Tendergreen to race 3 is determined by the $R 3$ gene and was expressed by a hypersensitive reaction, which was associated with a rapid increase in lipid peroxidation between 8 and $12 \mathrm{~h}$ after inoculation. Five main isoforms of SOD were resolved by native PAGE. Three further minor isoforms of SOD showed a strong increase in activity during the hypersensitive reaction (Ádám et al., 1995). In previous studies, the most severe infection of strawberry leaves by M. fragariae was found to occur within 12 to $96 \mathrm{~h}$ of leaf wetness and inoculation (Elliott, 1988; Carisse et al., 2000). With the growth of conidia, total SOD activity in the four strawberry cultivars increased and then peaked $2 \mathrm{~d}$ after inoculation, a pattern that presumably reflects the oxidative effects of $M$. fragariae. With the maturity and senescence of strawberry leaves, TPC and total SOD activity began to slowly decrease $4 \mathrm{~d}$ after inoculation; however, specific SOD activity showed a significant positive linear effect after inoculation. This provides evidence that SODs play an important role in protecting cells and tissues against biological stress.

SODs are metal-containing enzymes that are present in virtually all living organisms, including animals, plants and microorganisms, and are closely related to the metabolism of trace elements, e.g. copper $(\mathrm{Cu})$, zinc $(\mathrm{Zn})$, iron $(\mathrm{Fe})$ and manganese $(\mathrm{Mn}) . \mathrm{Mn}$ SOD is located in mitochondria, Fe SOD in chloroplasts and $\mathrm{Cu}$ and $\mathrm{Zn}$ SODs in both the cytosol and chloroplasts (Bowler et al., 1994). In a previous study, six isozymes were detected in control plants of Kent (HS), Honeoye (MR) and Joliette (HR), and some synthesized isozymes appeared or disappeared after inoculation (Ehsani-Moghaddam et al., 2006). In our study, a larger number of SOD isozymes were detected in control plants of Kent (HS), Joliette (HR), SJ8976-1 and APF029-4 (MR), that is, 14, 13, 13 and 15, respectively. After inoculation, there were no differences for Kent and APF029-1, but for Joliette and SJ8976-1, the number of SOD isozymes increased to 15 as a result of two newly synthesized SOD isozymes (i.e., $\mathrm{R}_{\mathrm{f}}=0.31$ and 0.34 ) without reduction of bands. The two synthesized SOD isozymes are believed to be associated with leaf spot resistance. This finding also indicates that the kinds of SODs vary by strawberry cultivar. Inoculation induced changes in SOD isozymes, in both quantity and quality, which could be linked to the differing susceptibility of strawberries to $M$. fragariae and other environmental stresses.

In conclusion, based on the analysis of SOD activity and electrophoretic analysis of isozymes, the four strawberry cultivars showed different susceptibilities to $M$. fragariae. This demonstrates that HR and MR cultivars possess an advanced antioxidant defense system, which is partly attributable to the increase in SOD activities and changes in concentration of the SOD isozymes. Future research should focus on separating the different SOD isoforms and controlling experimental conditions for different strawberry cultivars, in order to select highly disease-resistant cultivars through hybridization or transgene technology.

\section{References}

Ádám, A. L., Bestwick, C. S., Barna, B., \& Mansfield, J. W. (1995). Enzymes regulating the accumulation of active oxygen species during the hypersensitive reaction of bean to Pseudomonas syringae pv. phaseolicola. Planta, 197, 240-249. http://dx.doi.org/10.1007/BF00202643

Anderson, J. A. (2002). Catalase activity, hydrogen peroxide content and thermotolerance of pepper leaves. Scientia Horticulturae, 95, 277-284. http://dx.doi.org/10.1016/S0304-4238(02)00076-6

Beauchamp, C., \& Fridovich, I. (1971). Superoxide dismutase. Improved assays and an assay applicable to acrylamide gels. Analytical Biochemistry, 44(1), 276-287. http://dx.doi.org/10.1016/0003-2697(71)90370-8

Bowler, C., Van Camp, W., Van Montagu, M., \& Inzé, D. (1994). Superoxide dismutase in plants. Critical Reviews in Plant Sciences, 13(3), 199-218. http://dx.doi.org/10.1080/07352689409701914

Bowler, C., Van Montagu, M., \& Inzé, D. (1992). Superoxide dismutase and stress tolerance. Annual Review of Plant Physiology and Plant Molecular Biology, 43, 83-116. http://dx.doi.org/10.1146/anneruv.arplant.43.1.83

Bradford, M. M. (1976). A rapid and sensitive method for the quantification of microgram quantities of protein utilizing the principle of protein-dye binding. Analytical Biochemistry, 72, 248-254. http://dx.doi.org/10.1016/0003-2697(76)90527-3

Carisse, O., Bourgeois, G., \& Duthie, J. A. (2000). Influence of temperature and leaf wetness duration on infection of strawberry leaves by Mycosphaerella fragariae. Phytopathology, 90(10), 1120-1125. 
http://dx.doi.org/10.1094/PHYTO.2000.90.10.1120

Carisse, O., \& Kushalappa, A. C. (1989). Effect of media, $\mathrm{pH}$ and temperature on spore production and of inoculum concentration on number of lesions produced by Cercospora carotae. Phytoprotection, 70, 119-124.

Casano, L. M., Martin, M., \& Sabater, B. (1994). Sensitivity of superoxide dismutase transcript levels and activities to oxidative stress is lower in mature-senescent than in young barley leaves. Plant Physiology, 106(3), 1033-1039.

Chaitanya, K. V., Sundar, D., Masilamani, S., \& Ramachandra Reddy, A. (2002). Variation in heat stress-induced antioxidant enzyme activities among three mulberry cultivars. Plant Growth Regulation, 36(2), 175-80. http://dx.doi.org/10.1023/A:1015092628374

Dale, J. L., \& Fulton, J. P. (1957). Severe loss from strawberry leaf spot in Arkansas in 1957. Plant Disease Reporter, 41(8), 681-682.

Davis, B. J. (1964). Disc electrophoresis. II. Method and application to human serum proteins. Annals of the New York Academy of Sciences, 121, 404-427. http://dx.doi.org/10.1111/j.1749-6632.1964.tb14213.x

Delhomez, N., Carisse, O., Lareau, M., \& Khanizadeh, S. (1995). Susceptibility of strawberry cultivars and advanced selections to leaf spot caused by Mycosphaerella fragariae. HortScience, 30(3), 592-595.

Ehsani-Moghaddam, B., Charles, M. T., Carisse, O., \& Khanizadeh, S. (2006). Superoxide dismutase responses of strawberry cultivars to infection by Mycosphaerella fragariae. Journal of Plant Physiology, 163, 147-153. http://dx.doi.org/10.1016/j.jplph.2005.04.025

Elliott, V. J. (1988), Response models for conidiospore germination and germ tube elongation of Mycosphaerella fragariae as influenced by temperature and moisture. Phytopathology, 78(6), 645-650. http://dx.doi.org/10.1094/Phyto-78-645

Fall, J. (1951). Studies on fungus parasites of strawberry leaves in Ontario. Canadian Journal of Botany, 29(4), 301-315. http://dx.doi.org/10.1139/b51-029

Foyer, C. H., \& Noctor, G. (2000). Oxygen processing in photosynthesis: regulation and signalling. New Phytologist, 146, 359-388. http://dx.doi.org/10.1046/j.1469-8137.2000.00667.x

Fulton, R. H. (1958). Studies on strawberry leaf spot in Michigan. Michigan Agricultural Experiment Station Quarterly Bulletin, 40, 581-588.

Hernández, J. A., Olmos, E., Corpas, F. J., Sevilla, F., \& del Rio, L. A. (1995). Salt induced oxidative stress in chloroplasts of pea plants. Plant Sciences, 105, 151-167. http://dx.doi.org/10.1016/0168-9452(94)04047-8

Khanizadeh, S., Buszard, D., Carisse, O., \& Thibodeau, P. O. (1996). 'Joliette' strawberry. HortSciences, 31(6), 1036-1037.

Kuźniak, E., \& Sklodowska, M. (2004). The effect of Botrytis cinerea infection on the antioxidant profile of mitochondria from tomato leaves. Journal of Experimental Botany, 55, 605-612. http://dx.doi.org/10.1093/jxb/erh076

Maas, J. L. (1984). Compendium of Strawberry Diseases. APS Press, St. Paul, Minn.

Manganaris, A. G., \& Alston, F. H. (1992). Inheritance and linkage relationships of peroxidase isoenzymes in apple. Theoretical and Applied Genetics, 83, 392-399. http://dx.doi.org/10.1007/BF00224288

Matters, G. L., \& Scandalios, J. G. (1986). Effect of the free radical-generating herbicide paraquat on the expression of the superoxide dismutase (SOD) genes in maize. Biochimica et Biophysica Acta, 882, 29-38. http://dx.doi.org/10.1016/0304-4165(86)90051-6

McCord, J. M., \& Fridovich, I. (1969). Superoxide dismutase: an enzymic function for erythrocuprein (hemocuprein). Journal of Biological Chemistry, 244(22), 6049-6055.

Miyazawa, J., Kawabata, T., \& Ogasawara, N. (1998). Induction of an acidic isozyme of peroxidase and acquired resistance to wilt disease in response to treatment of tomato roots with 2-furoic acid, 4-hydroxybenzoic hydrazide or salicylic hydrazide. Physiological and Molecular Plant Pathology, 52(2), 115-126. http://dx.doi.org/10.1006/pmpp.1997.0141

Perl-Treves, R., \& Galun, E. (1991). The tomato $\mathrm{Cu}, \mathrm{Zn}$ superoxide dismutase genes are developmentally regulated and respond to light and stress. Plant Molecular Biology, 17, 745-760. http://dx.doi.org/10.1007/BF00037058 
Plakidas, A. G. (ed.). (1965). Strawberry diseases. Louisiana State University Press, Baton Rouge, LA.

Reuveni, R., Shimoni, M., Karchi, Z., \& Kué, J. (1992). Peroxidase activity as a biochemical marker for resistance of muskmelon (Cucumis melo) to Pseudoperonospora cubensis. Phytopathology, 82,749-753. http://dx.doi.org/10.1094/Phyto-82-749

Ros Barceló, A., Pomar, F., López-Serrano, M., \& Pedreño, M. A. (2003). Peroxidase: a multifunctional enzyme in grapevines. Functional Plant Biology, 30(6), 577-591. http://dx.doi.org/10.1071/FP02096

Scandalios, J. G. (1993). Oxygen stress and superoxide dismutases. Plant Physiology, 101(1), 7-12.

Smirnoff, N. (1998). Plant resistance to environmental stress. Current Opinion Biotechnology, 9(2), $214-219$. http://dx.doi.org/10.1016/S0958-1669(98)80118-3

SAS Institute. (1989). SAS user's guide: Statistics. Version 6. Cary, NC, USA: SAS Institute.

Tsang, E. W., Bowler, C., Hérouart, D., Van Camp, W., Villarroel, R., Genetello, C., ... Inzé, D. (1991). Differential regulation of superoxide dismutases in plants exposed to environmental stress. The Plant Cell, 3(8), 783-792. http://dx.doi.org/10.1105/tpc.3.8.783

Wang, B., Lüttge, U., \& Ratajczak, R. (2004). Specific regulation of SOD isoforms by NaCl and osmotic stress in leaves of the $\mathrm{C}_{3}$ halophyte Suaeda salsa L. Journal of Plant Physiology, 161, $285-93$. http://dx.doi.org/10.1078/0176-1617-01123

Wu, G., Wilen, R. W., Robertson, A. J., \& Gusta, L. V. (1999). Isolation, chromosomal localization and differential expression of mitochondrial manganese superoxide dismutase and chloroplastic copper/zinc superoxide dismutase genes in wheat. Plant Physiology, 120(2), 513-520. http://dx.doi.org/10/1104/pp.120.2.513

\section{Copyrights}

Copyright for this article is retained by the author(s), with first publication rights granted to the journal.

This is an open-access article distributed under the terms and conditions of the Creative Commons Attribution license (http://creativecommons.org/licenses/by/3.0/). 